\title{
Relationship Marketing, Long Term Orientation and Customer Loyalty in Higher Education
}

\author{
Muhammad Mujtaba Abubakar \\ Sany Sanuri Mohd Mokhtar
}

School of Business Management, Universiti Utara Malaysia, Sintok, Kedah, Malaysia

\section{Doi:10.5901/mjss.2015.v6n4p466}

\begin{abstract}
Recent policy changes, globalization and competition have called for the application of marketing models in the management of the higher educational institutions around the world. This study conceptualizes and empirically validates a model exploring the relationship between key relational constructs and customer loyalty among university students. A sample of 416 Nigerian university students was taken through multi-stage cluster sampling procedure. Partial Least Squares structural equation modelling was employed to analyse the data. Results suggest that the constructs of bonding, communication and personalization have significant effect on student satisfaction and trust which in turn predict student loyalty. Further, individual student long term orientation has moderating effect on the path between satisfaction and loyalty as against the path between trust and loyalty Theoretical and practical implications of the study were discussed and a conclusion drawn.
\end{abstract}

Keywords: Relationship marketing, customer loyalty, long term orientation, high education sector

\section{Introduction}

Research in the domain of services marketing has come a long way particularly with the advent of relationship marketing (RM) which seeks to strengthen the economic and social ties between customers and service providers for sustainable competitive advantage (Gummeson \& Gronroos, 2012). The basic premise upon which RM rests is that understanding customer needs and enhancement of their experience is the key to customer retention, company growth and profitability (Morgan \& Hunt, 1994). In effect, although both current and prospective customers are important to a business, to retain one existing customer is 5 to 6 times more cost effective than attracting one new customer (Ackerman \& Schibrowskey, 2007). This is consistent with the assumption of social exchange theory (SET, Blau, 1964) which suggests that satisfied and confident customers are likely to reciprocate the favorable treatment they received from the organization by repeat purchase, positive WOM and good ambassadorship. Since its introduction by Berry in 1983, RM has had a proportionate share of research application especially in banking and retail business. However, the education sector has received marginal research attention which according to Das (2009) accounted for only 0.8 per cent of RM studies. This is astonishing given the critical role of higher education sector (HE) in the development agenda of nations.

Already, the global higher education (HE) market is well established especially in the United States, United Kingdom, and other English speaking countries such as Canada and Australia where marketing departments occupy distinctive positions in the organisational structure of HEls (Ramachandran, 2010). In Nigeria, with a total of 128 accredited universities intense competition among universities is evident (World Education News \& Reviews, 2013). Public funding of education remains between $4 \%$ and $16 \%$ of annual budgets as against the $26 \%$ recommended by UNESCO (US Embassy in Nigeria, 2013). Equally disturbing is international student mobility. Anecdotal evidence has shown that in 2009/2010, Nigeria was the $17^{\text {th }}$ largest source of undergraduate international students and $19^{\text {th }}$ largest source of international graduate students in the US (US Embassy in Nigeria, 2013). Consequently, the need to develop strategies for the attraction and retention of students by Nigerian universities has become imperative.

Meanwhile, RM research applied to HES lean heavily on the validation of such relational dynamic as satisfaction (e.g., Douglas, McCelland \& Davis, 2008; Nesset \& Helgesen, 2009 ), reputation (Purgalia \& Zaksa, 2012), service quality (e.g., Nesset \& Helgesen, 2009), commitment (Hennig-Thurau, Langer \& Hansen,2001) and image (Purgalia \& Zaksa, 2012) to the neglect of key relational constructs like bonding, communication and personalisation.

This paper aims to achieve three research questions: (i) investigates the influence of bonding, communication and personalisation on customer satisfaction and trust (ii) examines the mediating effect of customer satisfaction and trust on 
the relationship between RM and customer loyalty, and (iii) explore the contingent role LTO on the relationship between customer satisfaction, trust and customer loyalty. The rest of the paper is organized as follows: Introduction is followed by theoretical background. Next, the research methodology was outlined after which the results were presented and finally discussed.

\section{Theoretical Background}

\subsection{Relationship Marketing}

Relationship marketing was defined by Gronroos (1996) as identifying, establishing, maintaining, and enhancing relationships with customers and other stakeholders, at a profit. Morgan and Hunt (1994) gave a widely accepted definition of RM as all marketing activities directed towards establishing, developing, and maintaining successful relational exchanges. In educational context, RM encompasses strategies designed to attract, establish and consolidate relationship with stakeholders like students, parents, reference groups and relevant government agencies; with emphasis on retaining existing students and canvassing for prospects (Moore \& Bowden-Everson, 2012).

\subsection{Customer Loyalty}

Empirical evidence in the domain of RM reveals that customer loyalty is a strategic antecedent of competitiveness and long term profitability of business (Morgan \& Hunt, 1994). Meanwhile, customer loyalty has been defined variously by scholars. A commonly cited definition is that of Oliver (1999) who construed loyalty as a customer's deep attachment to a product or brand without recourse to situational factors and marketing efforts. In the context of this research, customer loyalty refers to student loyalty to the university which extend beyond the period in which a student is formally registered as a student to include social participation, alumni membership, and donation after graduation (Hennig-Thurau et al., 2001).

\subsection{Bonding}

Building viable bonds between service providers and customers is a primary target of RM. Bonding is conceptualized as strong emotional attachment between buyer and seller such that each party is committed to maintaining the relationship (Chattananon \& Trimetsoontorn, 2009). The work by Berry and Parasuraman (1991) relates bonds to customer satisfaction and trust. Strong link between bonding and customer satisfaction and trust is also suggested by the study conducted by Chiu, Hsieh, Li, \& Lee (2005) while the research by Robinson, Abbott, and Shoemaker (2005) explained how relational bonding tactics work to create customer loyalty. In the context of higher education, Ackerman and Schibrowsky (2007) indicates that social, financial and structural bonding initiatives could assist a college achieve student positive experience, satisfaction, confidence and loyalty. Hence, we hypothesised as follows:

$\mathrm{H1}$ : Bonding has significant positive impact on customer satisfaction

H2: Bonding has significant positive impact on trust

\subsection{Communication}

Communication, defined as the ability of a service organization to provide the customer with timely and credible information (Ndubisi \& Wah, 2005) influence all facets of relationship (Doney, Barry \& Russel, 2007). Substantial argument abound in the leading work by Morgan and Hunt (1994) that communication is strongly related to trust among relational partners and by abstraction customer satisfaction (Kantsperger \& Kunz, 2010). The study by Selnes (1998) reveals that communication is a correlates to customer satisfaction and customer trust. Evidence of link between communication, customer satisfaction and trust can also be found in the works of Ball, Coelho and Marchas (2004) and Doney et al. (2007). Thus, we hypothesize the following:

H3: Communication has significant positive impact on customer satisfaction

H4: Communication has significant positive impact on trust

\subsection{Customer Satisfaction}

Although, it has no universally accepted definition, scholars seem to concur that satisfaction refers to the discrepancy 
between expectation and outcome of a service or product experience (Churchill \& Suprenant, 1982).Where customer expectations are confirmed, the customer stays with the service provider, otherwise, he may exit or engage in negative word-of-mouth (WOM) without necessarily complaining (Zeitham, Berry, \& Parasuraman, 1996). Armstrong and Seng (2000) posit that customer satisfaction is primarily related to customer loyalty. Ehigie and Taylor's (2009) work bears a substantial argument in favour of the connection between customer satisfaction and customer loyalty in relational context. The study conducted by Kantsperger and Kunz (2010) stresses the key function of customer satisfaction in building loyalty among customers . Hence, we hypothesis as follows:

H5: Customer satisfaction has significant positive impact on customer loyalty

\subsection{Personalisation}

Personalisation is defined as the customisation of certain aspects of the service or its delivery, treating each customer as a unique individual with a unique set of requirements (Ball, Coelho \& Vilares, 2006). The work by Shen and Ball (2009) suggests that service personalization is ubiquitous and has three principal relationships, namely with satisfaction, trust and loyalty. According to the study by Halimi Halimi, Chavosh, \& Choshali, 2011) personalization is linked to relationship satisfaction. Extending the arguments in Shen and Ball (2009), Coelho and Henseler's (2012) study argues that customization is directly related to customer satisfaction, trust and customer loyalty. From the foregoing, we hypothesise as follows:

H6: Personalisation has significant positive impact on customer satisfaction

H7: Personalisation has significant positive impact on trust

\subsection{Trust}

Scholars consider trust as the corner stone of RM (Palmatier, Dant, Grewal \& Evans, 2006). Trust is defined as the customer's belief in the reliability and benevolence of a relationship partner (Morgan \& Hunt, 1994). Reliability connotes belief in competence to deliver service effectively (Doney et al., 2007). Benevolence on the other hand, describes a situation where the customer believes that the relational partner is acting in his or her best interest and would act beneficially towards him or her should new conditions arise for which there was no commitment (Coelho \& Henseler, 2012). Benevolence translate into loyalty through the feeling of security that it plants in the mind of the partner which is particularly true in the context of HES where many at times students are assisted by management and staff both socially, academically and even financially (Ackerman \& Schibrowsky, 2007). In their work, Kantsperger and Kunz (2010) stress the influence of trust on customer loyalty. Hence, we hypothesize the following:

H8: Trust has significant positive impact on customer loyalty

\subsection{Mediating Effect of Customer Satisfaction}

Customer satisfaction is a major outcome of marketing strategies and processes culminating in product re-patronage and subsequent loyalty (Churchill \& Surprenant, 1982). This explains why ample literature evidence shows that customer satisfaction is a mediating mechanism between antecedents and outcomes in relational contexts. The study by Wang, Liang and Wu (2008) suggest that customer satisfaction and trust mediate between bonding and customer loyalty. The work by Ball et al. (2004) argues that communication's effect on customer loyalty passes through customer satisfaction and trust. Substantial argument exists in Selnes's (1998) for the indirect relationship between communication and customer loyalty through customer satisfaction and trust. The study by Deb and Lemo-David (2013) stresses the intervening role of customer satisfaction and trust on the link between personalization and customer loyalty which corroborated the ideas of Coelho and Henseler (2012). Consequently, we hypothesize the following:

H9: Customer satisfaction mediates the relationship between bonding and customer loyalty

H10: Customer satisfaction mediates the relationship between communication and customer loyalty

H11: Customer satisfaction mediates the relationship between personalisation and customer loyalty

\subsection{Mediating Effect of Trust}

Morgan and Hunt (1994) argue that trust is a key relational mediator. Trust is both an antecedent and consequence of relationship marketing (Palmatier, et al., 2006). Doney et al. (2007) emphasizes the intervening role of trust on the link between antecedent and outcomes such as bonding (Liang \& Wang, 2008). Selnes (1998) highlights on the role of trust 
on the relationship between communication and relationship continuity consistent with the argument of Doney et al. (2007). According to Coelho and Henseler (2012) and Deb and Lomo-David (2013) there are strong direct and indirect relationships between personalization and customer loyalty with customer trust among other constructs as mediating variables. To this end, we hypothesise the following:

H12: Trust mediates the relationship between bonding and customer loyalty

H13: Trust mediates the relationship between communication and customer loyalty

H14: Trust mediates the relationship between personalisation and customer loyalty

\subsection{Moderating role of Long Term Orientation}

Empirical evidence of the effect of RM on customer loyalty is contradictory. While mainstream studies report significant relationships between the dependent and independent variables (e.g., Armstrong \& Seng, 2000; Ball et al., 2006; Kantsperger \& Kunz, 2010), there are evidences of insignificant relationships (e.g., Dagger \& David, 2012; Leverin \& Liljander, 2006).These mix findings, suggest the need to test interaction effect.

Meanwhile, the works of Hofstede (e.g., Hoftede, 1980) has triggered ample studies particularly on the impact of cultural values at the individual's level (see Patterson,Cowley, \& Prasongsukam, 2006). Extant literature suggest massive effect of cultural values on customer perception and behaviour (e.g., Ekiz \& Au, 2010; Fayolle, Basso \& Bouchard, 2010 ; Kueh \& Voon, 2007; Lai, He, Chou \& Zhou, 2013). Long term orientation (LTO), defined as the cultural value of viewing time holistically, and valuing both the past and the future which was originally Confucian cultural value is one of the most widely acclaimed time orientation measure (Bearden, Money \& Nevins, 2006). Scientific evidence demonstrates that individuals with LTO are inclined to future planning, perseverance and respect for norms and therefore able to make sacrifice for the future as against individuals with short term orientation that are concerned with immediate reward (Hsu \& Burns, 2012). Presumably, individuals with LTO shall prefer stable and long lasting social relationships on account of the social and economic benefits of relationship. This is consistent with social exchange theory (Blau, 1964) which suggests that individuals join and maintain relationship because of the social and economic gains they expect from such behavior.

Against this background, we hypothesize the following:

H15: Long term orientation moderate the relationship between customer satisfaction and customer loyalty

H16: Long term orientation moderate the relationship between trust and customer loyalty

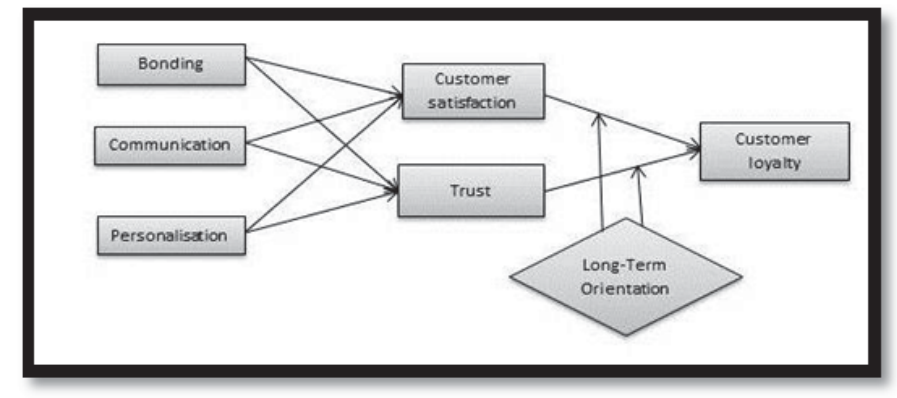

Figure 1: Conceptual Framework

\section{Methodology}

\subsection{Sample and Data collection}

A self-administered cross sectional survey was used to solicit data from 535 students of various programes in six federal universities of Nigeria using multi-stage cluster sampling. Participation was voluntary. Questionnaire was administered during lecture break and 480 students filled and returned the survey. However, we excluded a total of 64 questionnaires on account missing data and multivariate outliers leaving 416 effectives responses achieving a valid response rate of $77 \%$.

\subsection{Measures}

Measures were taken from prior studies and adapted to suit the HE context. Customer loyalty items were adapted from two sources (Caruana, 2002; Moore \& Bowden-Everson, 2012). Bonding items were adapted from two sources (Chattananon \& Trimetsoontorn, 2009; Hau \& Ngo, 2012) as well. Items of communication were adapted from Ndubisi and Wah (2005). The measures of communication were adapted from Ball et al. (2006). Customer satisfaction was measured by items adapted from the works of Hau and Ngo (2012). Meanwhile, trust was measured using items adapted 
from two sources (Hennig-Thurau et al., 2001; Morgan \& Hunt, 1994). Measures of LTO were taken from the work of Bearden et al. (2006). All measures were based on 5 Likert Scale, ranging from $1=$ strongly disagree to $5=$ strongly agree.

\subsection{Model Estimation}

We conducted data screening and preliminary analysis. Specifically, we assessed missing values and outliers, conduct normality and multicollinearity tests without any serious issues. We also assessed non-response bias which suggests we proceed with data analysis. Through PLS structural equation modelling SmartPLS (Ringle, Wende, \& Will, 2012), we assessed both the measurement and the structural model. The choice of PLS, a variance based SEM technique was based on two considerations: first, the present study rather sought to explore the social learning theory than confirm it. Secondly, the complexity of the research model, including six mediating and two moderating paths (Chin, 2010). To assess the measurement model's internal consistency, we used Cronbach's Alpha, composite reliability, convergent and discriminant validity. Cronbach's Alpha coefficients range between 0.71 and 0.84 while composite reliability coefficients range between 0.83 and 0.89 , exceeding the threshold of 0.70 (Nunnally, 1978) which indicated adequate internal consistency reliability of measures (Nunnally, 1978). Factor loadings were adequate as they range between 0.71 and 0.81. To achieve model fit, we deleted 7 items whose outer loadings fall below 0.7 (Chin, 2010) to arrive at the revised model. Convergent and discriminant validity of the instruments were evaluated through the approaches developed for PLS context by Fornell and Larcker (1981). Accordingly, the AVE of each latent construct was above 0.5 indicating adequate convergent and discriminant validity. Further, as suggested by Fornell \& Larcker (1981) the square root of the AVE should be higher than the correlations among the latent variables which have been achieved.

Table 1.0: Item Loading, Internal Consistency, Average Variance Extracted and R Square

\begin{tabular}{|c|c|c|c|c|c|c|}
\hline Construct & Indicator & Loadings & Composite reliability & AVE & Cronbach's Alpha & R Square \\
\hline \multirow[t]{4}{*}{ Bonding } & BON01 & .728 & .849 & .585 & .763 & \\
\hline & BON02 & .791 & & & & \\
\hline & BONO3 & .781 & & & & \\
\hline & BONO4 & .757 & & & & \\
\hline \multirow[t]{5}{*}{ Customer loyalty } & CLOY02 & .749 & .865 & .561 & .804 & .461 \\
\hline & CLOY03 & .799 & & & & \\
\hline & CLOY04 & .734 & & & & \\
\hline & CLOY05 & .709 & & & & \\
\hline & CLOY06 & .752 & & & & \\
\hline \multirow[t]{3}{*}{ Communication } & COM01 & .769 & .837 & .631 & .708 & \\
\hline & COM02 & .813 & & & & \\
\hline & COM03 & .800 & & & & \\
\hline \multirow[t]{6}{*}{ Customer satisfaction } & CS01 & .789 & .885 & .562 & .844 & .432 \\
\hline & $\mathrm{CS} 02$ & .721 & & & & \\
\hline & $\mathrm{CSO3}$ & .746 & & & & \\
\hline & $\mathrm{CSO} 4$ & .754 & & & & \\
\hline & CS05 & .733 & & & & \\
\hline & CS06 & .752 & & & & \\
\hline \multirow[t]{4}{*}{ Long-term orientation } & LTO01 & .769 & .829 & .548 & .728 & \\
\hline & LTO02 & .730 & & & & \\
\hline & LTO03 & .726 & & & & \\
\hline & LTO07 & .734 & & & & \\
\hline \multirow[t]{4}{*}{ Personalization } & PER01 & .754 & .862 & .611 & .788 & \\
\hline & PER02 & .808 & & & & \\
\hline & PER03 & .788 & & & & \\
\hline & PER04 & .775 & & & & \\
\hline \multirow[t]{5}{*}{ Trust } & TR02 & .753 & .868 & .569 & .810 & .494 \\
\hline & TR03 & .750 & & & & \\
\hline & TR04 & .772 & & & & \\
\hline & TR05 & .772 & & & & \\
\hline & TR06 & .723 & & & & \\
\hline
\end{tabular}

We assessed the structural model by applying the bootstrapping procedure with 500 bootstrap samples and 416 cases to examine the significance of the path coefficients (Chin, 2010). We tested mediation effect by PLS approach in which we evaluated the significance of relevant path coefficients via bootstrap (Chin, 2010). To test moderation, we apply the product term approach given that our moderating variable is a continuous variable (Henseler \& Fassott 2010) [see figure 
2.0].

Table 2.0: Results of Hypotheses Testing

\begin{tabular}{|c|c|c|c|c|c|c|}
\hline No. & Hypotheses path & Path Coefficients & Standard Error & T value & P Value & Decision \\
\hline $\mathrm{H} 1$ & BON $\Rightarrow$ CS & .202 & .047 & 4.354 & .000 & supported \\
\hline $\mathrm{H} 2$ & BON $\rightarrow$ TR & .310 & .044 & 7.017 & .000 & supported \\
\hline $\mathrm{H} 3$ & COM $>C S$ & 251 & .051 & 4.923 & .000 & supported \\
\hline $\mathrm{H} 4$ & $\mathrm{COM} \rightarrow \mathrm{TR}$ & .302 & .047 & 6.468 & .000 & supported \\
\hline H5 & CS $>$ CLOY & .402 & .051 & 7.841 & .000 & supported \\
\hline $\mathrm{H} 6$ & PER $->C S$ & .359 & .046 & 7.851 & .000 & supported \\
\hline $\mathrm{H} 7$ & PER $>>$ TR & .257 & .047 & 5.512 & .000 & supported \\
\hline $\mathrm{H} 8$ & TR $>$ CLOY & .273 & .055 & 4.932 & .000 & supported \\
\hline H9 & BON $>C S ~>C L O Y$ & .081 & .022 & 3.691 & .000 & supported \\
\hline $\mathrm{H} 10$ & COM $>$ CS $>$ CLOY & .101 & .025 & 4.036 & .000 & supported \\
\hline H11 & PER $>C S$ $>$ CLOY & .144 & .026 & 5.551 & .000 & supported \\
\hline $\mathrm{H} 12$ & BON $>$ TR $>$ CLOY & .085 & .021 & 4.030 & .000 & supported \\
\hline H13 & COM $>$ TR $>$ CLOY & .082 & .021 & 3.926 & .000 & supported \\
\hline H14 & PER $>>$ TR $>$ CLOY & .070 & .020 & 3.508 & .000 & supported \\
\hline H15 & CS * LTO $>$ CLOY & -.127 & .073 & 1.736 & .042 & supported \\
\hline $\mathrm{H} 16$ & TR * LTO $>$ CLOY & .101 & .071 & 1.411 & .079 & Not supported \\
\hline
\end{tabular}

***: $p<0.001 ;{ }^{* *} p<0.01 ;{ }^{*} p<0.05$

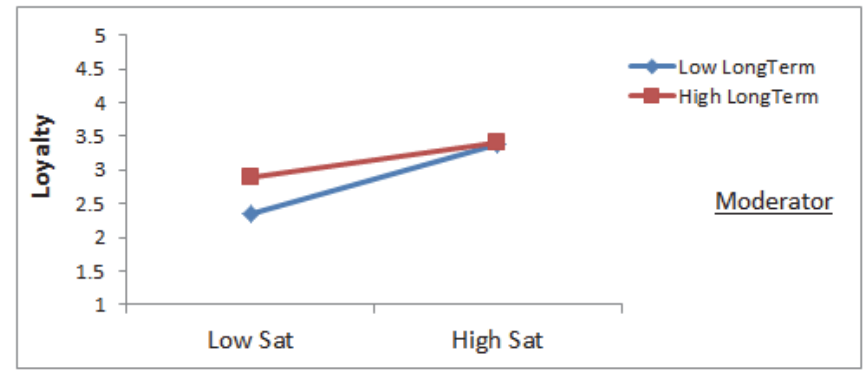

Figure 2: Interaction Effect of Customer satisfaction and LTO on customer loyalty

We assessed the coefficients of determination for the three endogenous variables. The R2 values for customer loyalty, customer satisfaction and trust are $0.46,0.43$ and 0.49 respectively. Thus, the combined effects of customer satisfaction and trust explained 46 per cent of the variation in customer loyalty. We consider the variance as acceptable (Chin, 1998). The effect sizes recorded range from small to medium in accordance with Cohen's (1988) criteria. As for predictive relevance of the research model, the cross-validation redundancy measures $\left(Q^{2}\right)$ for the three endogenous latent variables are $0.25,0.27$ and 0.23 for customer loyalty, trust and customer satisfaction respectively. Since all the crossvalidation redundancy measures are above zero, we ascertained the predictive relevance of the research model in line with Chin (2010)

\section{Results}

Results show that the hypothesized significant positive relationships between bonding and customer satisfaction $(\beta=$ $0.202, t=4.354, p<0.000)$, bonding and trust $(\beta=0.310, t=7.017, p<0.000)$, communication and customer satisfaction $(\beta=0.251, t=4.923, p<0.000)$, communication and trust $(\beta=0.302, t=6.468, p<0.000)$, customer satisfaction and loyalty $(\beta=0.402, t=7.841, p<0.000)$, personalization and customer satisfaction $(\beta=0.359, t=7.851, p<0.000)$, personalization and trust $(\beta=0.257, t=5.512, p<0.000)$, trust and customer loyalty $(\beta=0.273, t=4.932, p<0.000)$ were all supported, consistent with prior research on the significant relationship between bonding and customer satisfaction (Bowden, 2013; Liang \& Wang, 2008) and trust (Palmatier et al., 2006; Rodriguez \& Wilson, 2002);Communication and customer satisfaction (Hau \& Ngo, 2012; Ndubisi \& Wah, 2005) and trust (Doney et al., 2007; Ndubisi et al., 2007); customer satisfaction and loyalty (Moore \& Bowden-Everson, 2012; Nesset \& Helgesen, 2009); personalization and customer satisfaction (Bettencourt \& Gwinner, 1996; 2 ; Wierich \& Zielke, 2014) and trust (Ball et al., 
2006; Coelho \& Henseler, 2012) and trust and customer loyalty (Kantsperger \& Kunz, 2010). Similarly, the indirect hypotheses on the significant mediating effect of customer satisfaction on the relationships between bonding $(\beta=0.81, t$ $=3.691, p<0.000)$.), communication $(\beta=0.101, t=4.036, p<0.000)$, personalization $(\beta=0.144, t=5.551, p<0.000)$ and customer loyalty were supported. In the same vein, the indirect hypotheses on the significant mediating effect of trust on the relationship between bonding $(\beta=0.085, t=4.030, p<0.000)$, communication $(\beta=0.085, t=3.926, p<0.000)$, personalization $(\beta=0.070, t=3.508, p<0.000)$ and customer loyalty were supported consistent with prior studies highlighted above.

Meanwhile, the hypothesis on the moderating role of LTO on the relationship between customer satisfaction and customer loyalty was supported $(\beta=-0.127, t=1.736, p<0.042)$ but the final hypothesis on the moderating role of LTO on the relationship between trust and customer loyalty was not supported $(\beta=0.101, t=1.411, p<0.079)$.

\section{Discussion}

The aim of this research was to validate an RM model for HE sector and in particular explore the moderating effect of LTO on the relationship between relational constructs and customer loyalty. The significant relationship found between the independent and the mediating variables is not surprising because bonds such as tuition waivers, friendliness of staff should naturally boost student satisfaction and confidence. So also relevant and trustworthy information should instill confidence and reinforce student positive experience. It's understood also that customized university services like student-professor interaction and staff advisor services improve student's satisfaction and trust. The significant effect of customer satisfaction and trust on customer loyalty is instructive and consistent with the suggestion of SET(Blau, 1964) that relational partners who received benefits such as satisfaction, confidence and personalized services tend to reciprocate with loyalty.

The findings of this study provide significant insight unto the moderating role of LTO on the link between customer satisfaction and loyalty. Hence, an individual student with LTO should naturally desire long term relationship with university through the predisposition for planning and respect for tradition as against students with short term orientation. A plausible explanation for the insignificant moderating effect of LTO on the link between trust and customer loyalty may relates to the characteristics of the sample used in this study as students tend to be homogenous. Perhaps using former university students, consistent with our conceptualization of student loyalty, may produce a different result in future studies.

\subsection{Theoretical Implications}

This research has contributes to theory by empirically validating the role of service personalisation as a relational construct that received scant research attention. The study provides additional empirical evidence of SET applied to the domain of HE. Particularly, the significant moderating role of LTO on the link between customer satisfaction and outcome variable of customer loyalty is empirically validated. Taken together, the outcome of our research is a significant theoretical contribution to the on-going debate on the appropriateness of the metaphor of student as customer within the services marketing literature.

\subsection{Managerial Implications}

The findings of this study imply that to drive student loyalty, it is necessary to secure student's positive experience, satisfaction and confidence in the academic institutions. To achieve that, universities and other HEls must institute viable relational bonds that include tuition waivers, scholarship awards and functional campus services. There must also be good interactive communication system through such means as websites, university portal, emails and inter-personal communication. The results also highlights the strategic importance of university service personalisation especially in the areas of e-library web personalization features, information technology and guidance and counselling. A compelling finding of this study is the contingent role of LTO. Impliedly, individual students high in LTO are the more likely to value long term relationships and respect ethics, thus, tracking students' LTO in data base shall assist university administrators in managing their student profile more effectively.

\subsection{Limitations and Future Research Direction}

In spite of the numerous contributions of this study, it is not without limitations. The data for this study was crosssectional. Hence, future studies should try longitudinal designs given the fact that customer perception and attitude 
change over time. Because this study solicited data from university students exclusively, future studies should consider students from other components of HE such as colleges. The variances of $43 \%, 49 \%$ and $46 \%$ for customer satisfaction, trust and customer loyalty respectively recoded in this study indicate that several other factors also account for customer loyalty in HEls. Thus, the effects of relational construct like reciprocity, competence and the possible interaction role of cultural perspectives like masculinity/feminisms and individualism/collectivism should be examine by future studies.

\subsection{Conclusion}

The present research demonstrates that it will be in the best interest of universities in particular, and HEls as a whole, to apply a relationship marketing approach in the delivery of their educational services in view of the enormous challenges facing the sector, including falling public funding, international mobility and fierce competition for students enrolment. Managers of HEls would benefit tremendously from insights regarding drivers of customer loyalty through enhancement of value for students and improving the institution's financial performance.

\section{References}

Ackerman, R., \& Schibrowsky, J. (2007). A business marketing strategy applied to student retention: A higher education initiative. Baywood Publishing Co., Inc. 2007, 307-336. DOI: 10. 219/CS.9.3.d.

Armstrong, R. W., \& Seng, T. B. (2000). Corporate customer satisfaction in the baking industry of Singapore. International Journal of Bank Marketing 18(3), 97-111.

Ball, A. D., Coelho, P. S., \& Vilares, M. J. (2006). Service personalization and loyalty. Journal of Services Marketing, 206, 391- 403. [doi 101108 088760406 10691284]

Ball, D., Coelho, P. S. \& Machas, A. (2004). The Role of communication and trust in explaining customer loyalty: An extension of the European Customer Satisfaction Index Model, European Journal of Marketing, 38 (9/10), 1272-1293. doi: 10.1108/030905 60410548979.

Bearden, O. B., Money, R. B. \& Nevins, J. L. (2006). A measure of long-term orientation: development and validation. Journal of the Academy of Marketing Science, 34 (4), 456-467. doi: 10.1177/0092070306286706.

Berry, L. L., \& Parasuraman, A. (1991). Marketing services: Competing through quality, New York: Free Press.

Bettecourt, L. A., \& Gwinner, K. (1996). Customisation of the service experience: the role of the frontline employee. International Journal of Service Industry Management, 7 (2), 3-20. http:// dx. Org/10.1108/09564239610113442

Blau, P. M. (1964). Exchange and power in social life. New York: John Wiley \& Sons, Inc

Caruana, A. (2002). Service loyalty: The effects of service quality and the mediating roles of customer satisfaction. European Journal of Marketing, 30, 811-828. doi: 10.1108/039056021043081

Casielles, R., Alvarez, L., \& Martin, A. (2005). Trust as a key factor in successful relationships between consumers and retail service providers. The Service Industries Journal, 25(1), 83-101. Retrieved from http://dx.doi.org/10.1080/0264206042000302423

Chattananon, A., \& Trimetsoontorn, (2009). Relationship marketing: A Thai Case. International Journal of Emerging Markets, 4(3), $252-274$.

Chiu, H., Hsieh, Y., Li, Y. \& Lee, M. (2005). Relationship marketing and consumer switching behaviour, Journal of Business Research, 58, 16811689, doi: 10.1016/jjbusres.2004.11.005.

Chin, W. W. (2010). How to write up and report PLS analysis. In Esposito, V., et al. (eds), Handbook of Partial Least Squares (pp.655-688). New York: Springer-Verlag.

Churchill \& Surprenant (1982). Investigating into the determinants of customer satisfaction, Journal of Marketing Research, Nov 1982; 19, 000004; ABI/IMFORM Global

Coelho, P. S., \& Henseler, J. (2012). Creating customer loyalty through service customization. European Journal of Marketing, 46, $331-356$. http://dx.doi.org/10.1108/03090561211202503

Cohen, J. (1988). Statistical power analysis for the behavioral sciences. Hillsdale, NJ: Lawrence Erlbaum Associates.

Dagger, T. S. \& David, M. E. (2012). Uncovering the real effects of switching costs on the satisfaction-loyalty association; The critical role of involvement and relationship benefits, European Journal of Marketing, 46, 447-468. doi: 10 1108/0309056121202558

Das, K. (2009). RM Research (1994-2006): An academic literature review and classification. Marketing Intelligence and Planning, 27, 326-363. Doi: 10.1108/02634500910955236.

Deb, M., \& Lomo-David, E. (2013). Critical analysis of seller-customer bonding: Perception, retention, orientation and status. Journal of Management Policy and Practice, 14 (1)

Doney, P. M., Barry, J. M., \& Russel, A. (2007). Trust Determinants and Outcomes in Global B2B Services. European Journal of Marketing, 41(9/10), 1096-1116.

Ehigie, B. O., \& Taylor, M. (2009). Managing student loyalty to school after graduation through relationship marketing. The TQM Journal, 21(5), 502-516. doi: 10.1108/17542730910983416

Ekiz, E. H., \& Au, N. (2011). Comparing Chinese and American attitudes towards complaining. International Journal of Contemporary Hospitality Management, 20 (3),327-343.doi:10.11080959611111122514

Fang, T. (2003). A critique of Hofstede's Fifith national culture dimension. International Journal of cross cultural management, $2003,3,347$. doi:10.117711470595803003003006

Fayolle, A., Basso, O. and Bouchard, V. (2010). Three levels of Culture and Firms' Entrepreneurial Orientation: A research Agenda, Entrepreneurship \& Regional Development, 22, 7-8. doi: 10.1080/08985620903233952

Fornell, C., \& Larcker, D. F. (1981). Evaluating Structural Equation Models with unobservable variables and measurement error. Journal of 
Marketing Research, 18, 39-50

Gronroos, C. (1996). Relationship Marketing: Strategic and Tactical Implications. Management Decisions, 34(3), 5-14.

Gummeson, E., \& Groonroos, C. (2012). The emergence of the new service marketing: nordic school perspective. Journal of Service Management, 23(4), 479-497.

Halimi, A. B., Chavosh, A. \& Choshali, S. H. (2011). The influence of relationship marketing tactics on customer's loyalty in B2B relationship - the role of communication and personalization. European Journal of Economics, Finance and Administrative Sciences, 31, 49-56

Hau, L. N., \& Ngo, L. V. (2012). Relationship Marketing in Vietnam: An Empirical Study, Asia Pacific Journal of Marketing and Logistics, 4(2), 225235. doi: $10.1108 / 13555851211218039$

Hennig-Thurau, T., Langer, M. F. \& Hansen, U. (2001). Modelling and managing student loyalty: An approached based on the concept of relationship quality. Journal of Services Research, 3 (4), 331-344.

Henseler, J., \& Fassott, G. (2010). Testing Moderating Effects in PLS Path Models: An Illustration of Available Procedures. In V. Esposito Vinzi, W. W. Chin, J. Henseler \& H. Wang (Eds.), Han

Hofstede, G. (1980). Culture's Consequences: International Difference in Work-Related Values. Beverly Hills, CA: Sage.

Hsu, H., \& Burns, L. D. (2012). The effects of culture, long term orientation, and gender on consumers' perception of clothing values. Social Behaviour and Personality, 40 (10), 1585-1596. Htt://dx.doi.org/10.2224/sbp.2012.40.10,1585.

Kantsperger, R., \& Kunz, W. H. (2010). Consumer trust in service companies: A multiple mediating analysis. Managing Service Quality, 20(1), 425. doi: 10. 1108/09604521011011603

Kueh, K., \&Voon, B.(2007). Culture and service quality expectations: Evidence from generation Y consumers in Malaysia. International Journal of Service Quality, 17(6), 656-680. doi: 10.1108/09604520710834993

Lai, J., He, P., Cho, H. \& Zhou, L. (2013). impact of national culture on online consumer review behavior. Global Journal of Business Research, $7(1)$.

Leverin, A., \& Liljander, V. (2006). Does relationship marketing improve customer relationship satisfaction and loyalty? International Journal of Bank Marketing, 24(4), 232-251. doi 10. 1108/02652320610671338

Liang, C. \& Wang, W. (2008). How managers in the financial services industry ensure financial performance. The Service Industries Journal, 28 (2), 193-210. doi:10.1080/026420701842258.

Moore, D. \& Bowden-Everson, J. L. (2012). An appealing connection - The role of relationship marketing in the attraction and retention of students in an Australian tertiary context. Asian Social Science, 8 (14), doi: 10.5539/ass.v8n14p65.

Morgan, R. M., \& Hunt, S. D. (1994). The commitment-trust theory of relationship marketing. Journal of Marketing, 58(1994), 20-38.

Ndubisi, N. O., \& Wah, C. K. (2005). Factional discriminant analysis of the underpinnings of relationship marketing and customer satisfaction. International Journal of Bank Marketing, 23(7), 542-557.

Nesset, E. \& Helgesen, O. (2009). Modelling and managing student loyalty: A study of a Norwegian University college. Scandinavian Journal of Educational Research, 53 (4), 327-345. doi: 10.1080/00313830903043117.

Nunnally, J. C. (1978). Psychometric theory, $2^{\text {nd }}$ Ed. New York: McGraw Hill.

Oliver, R. L. (1999). Whence Customer Loyalty? Journal of Marketing, 63, 33-44.

Palmatier, W. P., Dant, R. P. Grewal, D. \& Evans, K. R. (2006). Factors influencing the effectiveness of relationship marketing: A meta -Analysis, Journal of Markting,70, 136-153

Patterson, P. G., Cowley, E. \& Prasongsukam (2006). Service failure recovery: The moderating impact of individual-level cultural value orientation on perceptions of justice. International Journal of Research in Marketing, 23 (3), 263-277, doi: 10.1016/j.jijesmar. 2006. 02.004.

Purgailis, M. \& Zaksa, K. (2012). The impact of perceived service quality on student loyalty in higher education institutions. Journal of Business Management, 6, 138-152.

Ramachandran, N. T. (2010). Marketing framework in higher education: Addressing aspirations of students beyond conventional tenets of selling products. International Journal of Educational Management,24 (6), 544-556. doi: 10.1108/09513541011067700.

Ringle, C. M., Wende, S., \& Will, A. (2010). Finite Mixture Partial Least Squares Analysis: Methodology and Numerical Examples. In Handbook of partial least squares: concepts, methods and applications in marketing and related fields (p. 193-218). Heidelberg, Dordrecht, London, New York: Springer.

Robinson, C. Abbott, J. \& Shoemaker, S. (2005). Recreating cheers: An analysis of relationship marketing as an effective marketing technique for quick service restaurants, International Journal of Contemporary Hospitality Management, 17 (7), 590-599. doi: $10.1108 / 09596110510620663$.

Rodriguez, C. M., \& Wilson, D. T. (2002). Relationship bonding and trust as a foundation for commitment in U.S - Mexican strategic alliances: A structural equation modelling approach, Journal of International Marketing, 10, 4, 53-76

Selnes, F. (1998). Antecedents and consequences of trust and satisfaction in buyer-seller relationships, European Journal of Marketing, 32, 305322

United States Embassy in Nigeria (2012). Nigeria education fact sheet, Retrieved http://nigeria.usembassy.gov

Wang, W., Liang, C. \& Wu, Y. (2006). Relationship bonding tactics and customer behavioural loyalty: Behavioral sequence in Taiwn's information services industry, Journal of Services Research, 6 (1), 31-57

World Education News \& Report (2013). Nigerian education fact sheet. Retrieved from http://wenr/.wes.org/wp

Zeithaml, V. A., Berry, L. L., \& Parasuraman, A. (1996). The behavioural consequences of service quality. Journal of Marketing, 60(2), 31-46. 